\title{
Distribution of mtDNA haplotypes in North Atlantic humpback whales: the influence of behaviour on population structure
}

\author{
Per J. Palsbøll ${ }^{1}$, Phillip J. Clapham ${ }^{2}$, David K. Mattila ${ }^{2}$, Finn Larsen ${ }^{3}$, Richard Sears ${ }^{4}$, \\ Hans R. Siegismund ${ }^{5}$, Johann Sigurjónsson ${ }^{6}$, Oswaldo Vasquez ${ }^{7}$, Peter Arctander ${ }^{1}$ \\ ${ }^{1}$ Department of Population Biology, Zoological Institute, University of Copenhagen, Universitetsparken 15 , \\ DK-2100 København $\varnothing$, Denmark \\ ${ }^{2}$ Cetacean Research Program, Center for Coastal Studies, Provincetown, Massachusetts 02657, USA \\ ${ }^{3}$ Greenland Fisheries Research Institute, Tagensvej 135, 1, DK-2200 København N, Denmark \\ ${ }^{4}$ Mingan Island Cetacean Study, Inc., 285 Green Street, St-Lambert, Quebec, Canada J4P 1T3 \\ ${ }^{5}$ Arboretum, The Royal Veterinary and Agricultural University, Kirkegårdsvej 3A, DK-2970 Hørsholm, Denmark \\ ${ }^{6}$ Marine Research Institute, Skúlagata 4, PO Box 1390, 121 Reykjavik, Iceland \\ ${ }^{7}$ Centro de Investigacciones de Biologia Marina, Universidad Autonoma de Santo Domingo, Jonas Salk 55, Santo Domingo, \\ Dominican Republic
}

\begin{abstract}
Samples from 136 humpback whales Megaptera novaeangliae, representing 5 feeding aggregations in the North Atlantic and 1 in the Antarctic, were analyzed with respect to the sequence variation in the mitochondrial ( $\mathrm{mt}$ ) control region. A total of 288 base pairs was sequenced by direct sequencing of asymmetrically amplified DNA. Thirty-one different haplotypes were identified. The nucleotide diversity for the total sample was estimated to be $2.6 \%$, which is high relative to other North Atlantic cetaceans. The degree of genetic differentiation in various subsets of the samples was estimated and tested for statistical significance by Monte Carlo simulations. Significant degrees of heterogeneity were found between the Antarctic and all North Atlantic areas, as well as between Iceland and the western North Atlantic samples. A genealogical tree was estimated for the 31 haplotypes and rooted with the homologous sequence from a fin whale Balaenoptera physalus. The branching pattern in the genealogical tree suggests that the North Atlantic Ocean has been populated by 2 independent influxes of humpback whales. The combined results from the homogeneity tests and the genealogical tree indicate that behaviour (in this case maternally directed site fidelity to a foraging area) can influence the population structure of marine cetaceans on an evolutionary time scale.
\end{abstract}

KEY WORDS: Philopatry · Population genetics · Mitochondrial control region · PCR

\section{INTRODUCTION}

While the dispersal and segregation of populations of terrestrial mammals are frequently influenced by geographic features or climatic characteristics, few such obvious barriers exist in the oceans. Consequently, we might expect population structure among the pelagic cetaceans to reflect this lack of constraint. Indeed, behavioural studies have shown that the humpback whale Megaptera novaeangliae is one of the widest-ranging mammals in the world, making annual migrations of up to $8000 \mathrm{~km}$ from high-latitude feeding grounds to breeding and calving areas in tropical waters (Dawbin 1966, Stone et al. 1990). However, while all studied populations of this species undertake such migrations, it is apparent that, during the summer feeding season, the whales exhibit more restricted movement and geographic segregation (Clapham \& Mayo 1987, Katona $\&$ Beard 1990, Clapham et al. 1993a).

In the North Atlantic, the identification of individual whales over the past $15 \mathrm{yr}$ has suggested the existence of a number of relatively discrete feeding aggrega- 
tions, fidelity to which is determined matrilineally (Katona \& Whitehead 1981, Katona \& Beard 1990). These areas include the Gulf of Maine (Clapham et al. 1993a), Newfoundland/Labrador (Perkins \& Whitehead 1977), the Gulf of St. Lawrence (Katona \& Beard 1990), West Greenland (Perkins et al. 1984) and Iceland (Sigurjonsson \& Gunnlaugsson 1990). Humpbacks are also known to feed in the waters of arctic and subarctic Norway (Christensen et al. 1992), although little is known of the current status of this population. As more individuals have been identified, an increasing number of humpbacks have been recorded in more than one feeding area, although the proportion remains very low relative to the total number of resightings (Katona \& Beard 1990). Within specific feeding areas, distribution is largely determined by the availability of prey (Payne et al. 1990).

With the exception of Norwegian humpbacks, whose migratory destination is presently unknown, whales from the various North Atlantic feeding aggregations all migrate to the West Indies each winter (Martin et al. 1984, Mattila et al. 1989, Katona \& Beard 1990). Furthermore, observations of whales from different high-latitude areas in the same competitive groups (Clapham et al. 1993b), and the spatial mixing that is evident throughout the West Indies breeding range, have strongly suggested that the North Atlantic population of this species constitutes a single panmictic unit.

The investigations noted above have recently been complemented by genetic studies based upon molecular analyses of skin samples collected as biopsies from free-ranging whales. Baker et al. (1993) examined worldwide variation in the mitochondrial (mt) control region and showed that humpback whales in the North Pacific, North Atlantic and Southern Ocean constitute separate populations with very limited inter-oceanic exchange. Within the North Pacific, highly significant differences in $m$ t haplotype frequencies have been found among whales from regions that behavioural studies have suggested represent different panmictic entities (Baker et al. 1990).

A natural extension of the molecular studies conducted to date is to test whether the observed segregation of individuals into different feeding aggregations within the same ocean is maintained over periods that are long enough to be of evolutionary significance. Given that the 2 factors which appear to determine present population structure (maternally directed foraging area philopatry and spatial distribution of preyl presumably are, from an evolutionary perspective, relatively plastic and short-lived phenomena, we might expect little or no reflection of these patterns in the genetic structure of the population.
We report here the results of an analysis of the distribution of substitutions in the nucleotide sequence of the mt control region (also called the D-loop) of 136 humpback whales from 5 feeding aggregations in the North Atlantic and 1 in the Antarctic. We find that, contrary to our expectations, the observed matrilineal fidelity to specific areas appears to have a significant effect on the overall North Atlantic population structure on an evolutionary time scale.

The $\mathrm{mt}$ genome is maternally inherited, nonrecombining, and evolves at a rate 5 to 10 times higher than single-copy nuclear sequences (Brown et al. 1979, Brown 1985). The control region is the only major non-coding region and most rapidly evolving part of the mt genome (Upholt \& Dawid 1977, Cann et al. 1984), making it particularly well suited for the study of intraspecific evolution. The combination of these characteristics makes the $\mathrm{mt}$ control region an ideal genetic marker for testing the hypothesis of long-term segregation of maternally directed feeding aggregations in an otherwise panmictic population. Although Hoelzel et al. (1991) and Baker et al. (1993) found that the cetacean mt control region evolved at a lower rate than that of other mammals, the present study shows a high degree of genetic variation within the North Atlantic humpback whale population, at levels similar to that observed in human populations (Vigilant et al. 1991). This variation has allowed us to detect statistically significant segregation, and to estimate a reliable genealogy for major clades of haplotypes.

\section{METHODS}

Sample collection and conservation. The samples included in this study were collected either as skin biopsies from free-ranging whales (Lambertsen 1987, Palsbøll et al. 1991) or as sloughed skin (Clapham et al. 1993c). Sampling was conducted on 4 feeding grounds: the Gulf of Maine, the Gulf of St. Lawrence, West Greenland and Iceland. A number of other whales sampled in Samana Bay, Dominican Republic (a breeding area), were later found from photoidentification to have been previously observed in the Newfoundland/Labrador area, or in the Gulf of Maine, thus providing additional samples for the study of genetic variation among high-latitude feeding aggregations. Eleven samples collected off the Antarctic Peninsula were also included to provide an outgroup as a frame of reference for interpreting the North Atlantic samples.

All sampled whales were photographically identified by variations in natural markings, specifically those of the ventral fluke pattern and the dorsal fin (Katona \& Whitehead 1981). All photographs were compared to 
ensure the exclusion of multiple samples from single individuals.

Sighting histories and knowledge concerning degree of consanguinity between individuals were available for many of the Gulf of Maine whales from a longterm study of identified individuals in that region (Clapham et al. 1993a). These data were used to confirm and interpret the results of the mtDNA analyses.

Samples were conserved in saturated sodium chloride with $25 \%$ dimethylsulfoxide at $-20^{\circ} \mathrm{C}$ (Amos \& Hoelzel 1991).

DNA extraction, amplification, sequencing and sex determination. DNA was extracted from the tissue samples following standard protocols with cell lysis in $1.0 \%$ SDS (sodium lauryl sulfate), $0.15 \mathrm{M}$ sodium chloride, $10 \mathrm{mM}$ Tris-HCl (pH 8.0), $1 \mathrm{mM}$ EDTA (ethylenediamine tetraacetic acid) and digested with proteinase $\mathrm{K}\left(100 \mu \mathrm{g} \mathrm{ml}^{-1}\right)$ at $65^{\circ} \mathrm{C}$ for a minimum of $3 \mathrm{~h}$ followed by phenol/chloroform extractions and precipitation with ethanol (Maniatis et al. 1982).

The nucleotide sequence of the $5^{\prime}$ end of the $\mathrm{mt}$ control region was determined by direct sequencing of asymmetrically amplified DNA by the polymerase chain reaction (PCR) (Gyllensten \& Erlich 1988, Saiki et al. 1988). Symmetric double-stranded amplification of the whole control region was performed with primers MT3 and MT4 (Table 1) in $20 \mu l$ reactions; $\left[0.067 \mathrm{M}\right.$ Tris- $\mathrm{HCl}(\mathrm{pH} 8.8), 0.002 \mathrm{M} \mathrm{MgCl}_{2}, 0.0166 \mathrm{M}$ $\mathrm{NH}_{3} \mathrm{SO}_{4}, 0.01 \mathrm{M} \beta$-mercaptoethanol, $0.2 \mu \mathrm{M}$ per nucleotide], $1 \mu \mathrm{M}$ for each primer, 0.4 units AmpliTaq ${ }^{\text {'" }}$ DNA polymerase and $10 \mathrm{ng}$ extracted genomic DNA. The temperature profile was: $1 \mathrm{~min}$ at $94^{\circ} \mathrm{C}, 1 \mathrm{~min}$ at $57^{\circ} \mathrm{C}$ and $3.5 \mathrm{~min}$ at $72^{\circ} \mathrm{C}$ for 28 cycles. For asymmetric amplification the primers MT4 and Mn312 were used (Table 1). Amplifications were conducted under the same conditions as above except that the total reaction volume was $50 \mu \mathrm{l}$, the annealing temperature $55^{\circ} \mathrm{C}$ and the extension time $1.5 \mathrm{~min}$ for 30 cycles. Blank extractions and blank PCR reactions were included as controls to detect possible contamination. Both strands were sequenced for approximately half of the samples. Sequencing was conducted according to the manufacturer's instructions (US Biochemicals, Inc.). MT4, Mn312, Mn196 and Mn152 were used as sequencing

Table 1. Primer sequences. F and $R$, respectively, denote a forward- or reverseoriented primer, with reference to the light strand

\begin{tabular}{|llll|}
\hline Primer code & \multicolumn{2}{l}{ Nucleotide sequence } & Source \\
\hline MT4-F & CCT CCC TAA GAC TCA AGG AAG & Arnason et al. (1993) \\
MT3-R & CAT CTA GAC ATT TTC AGT G & Arnason et al. (1993) \\
Mn312-R & CGT GAT CTA ATG GAG CGG CCA & This study \\
Mn152-R & GCA CGA ATT ACA TAA TGG TAT & This study \\
Mn196-F & ACT GAT AGC ACC TTC CAT GAG T & This study \\
\hline
\end{tabular}

primers (Table 1). The sex of each sampled whale was determined by a PCR-based method (Palsbøll et al. 1992).

Data analysis. Nucleotide diversity was estimated as defined by Nei \& Li (1979). The extent of genetic differentiation between various partitionings of samples was estimated using either the sequence $\left(K_{S T}\right)$ or haplotype $\left(H_{S T}\right)$ statistic proposed by Hudson and coworkers (Hudson 1992, Hudson et al. 1992, Roff \& Bentzen 1992). $K_{S T}$ is identical to $\gamma_{S T}$ defined by Nei (1982), except for the weighting of the average number of differences between the sampled sequences within each locality. For $K_{S T}$ (the statistic used in this study) the actual number of sampled sequences is used, whereas for $\gamma_{S T}$ each sample location is usually given the same weighting in the pairwise comparisons. The choice of statistic used for testing the level of significance in the pairwise comparisons was that suggested by Hudson et al. (1992). When the degree of variation was high or one of the 2 samples was small, the $K_{S T}$ statistic was chosen.

Samples in pairwise comparisons were considered to be significantly heterogeneous when the probability of obtaining the observed, or a more extreme, value of either $H_{S T}$ or $K_{S T}$ was less than 0.05 in 1000 Monte Carlo simulations (Hudson et al. 1992).

Homogeneity tests were performed by pairwise comparisons of samples in a hierarchical manner as follows: males/females within each area; residents/ non-residents (for the southern Gulf of Maine only see below); year/year; feeding aggregation/feeding aggregation; and hemisphere/hemisphere.

Homogeneous samples were combined in the subsequent comparisons. Other partitionings of the specimens were tested for homogeneity, and these are described in more detail in 'Results'.

The Gulf of Maine samples were divided into 'resident' and 'non-resident' individuals based upon the frequency with which an individual had been observed in the southern Gulf of Maine study area (Massachusetts Bay and the Great South Channel; see Clapham et al. 1993a). For the sampled individuals the overall mean number of days sighted per year was 4.3 (range $=0$ to $21.3 \mathrm{~d} \mathrm{yr}^{-1}$ ). Individuals with a mean of less than $4.3 \mathrm{~d} \mathrm{yr}^{1}$ were categorized as non-residents, and those with a mean above 4.3 as residents. The extent of genetic differentiation between residents and non-residents was estimated and tested for significance.

A rooted genealogical tree was estimated, with the homologous sequence from a North Atlantic fin whale Balaenoptera physalus as an 
outgroup (Arnason et al. 1991). Using the PHYLIP 3.5c computer package (Felsenstein 1993) a tree was estimated based on the maximum likelihood method. A total of 10 trees with random input order were estimated based on a transition/transversion ratio of $25: 1$ (the ratio that yielded the highest log-likelihood score). Using the Neighbor-joining method (Saitou \& Nei 1987), a consensus tree was estimated from 400 bootstrap samples generated from the original data set. Distance matrices were calculated using the algorithm defined by Kimura (1980) and input order randomized. The estimated topologies obtained from the maximum likelihood and Neighbor-joining methods were compared using the Kishino-Hasegawa-Templeton test (Kishino \& Hasegawa 1989) which is included in the PHYLIP 3.5c DNAML program.

\section{RESULTS}

\section{Samples and haplotypes}

The number of samples and the areas and years in which they were collected are summarized in Table 2.

The first 288 base pairs of the $5^{\prime}$ end of the mt control region were successfully sequenced in 136 individuals; the quality of these sequences has been demonstrated in a previous publication (Clapham et al. 1993c). A total of 36 polymorphic sites defined 31 haplotypes. With the exception of 1 deletion and 2 transversions, all substitutions were transitions. Fig. 1 shows the sequence of haplotype no. 9 (Table 3; see also Figs. 2 \& 3) aligned with a fin whale sequence (Arnason et al.
1991), and Table 3 summarizes the haplotype and sex of all specimens.

In the 11 specimens from the Antarctic Peninsula, 7 haplotypes were detected, 3 of which were found only in single specimens. Two Antarctic whales shared a haplotype with 1 North Atlantic whale from the Gulf of St. Lawrence (haplotype no. 10 in Table 3). Because of the unexpected nature of this discovery, all 3 specimens were amplified and sequenced a second time, with the same result. The 125 specimens from the North Atlantic divided into 25 haplotypes, of which 12 were represented by single individuals.

Comparisons with data previously published in a study of the worldwide variation in the $\mathrm{mt}$ control region of humpback whales (Baker et al. 1993) were not possible since the sequences concerned were not available from any of the common sequence databases. The portion of the control region analyzed appears to be different from that sequenced in this study, starting about 150 base pairs into the mt control region.

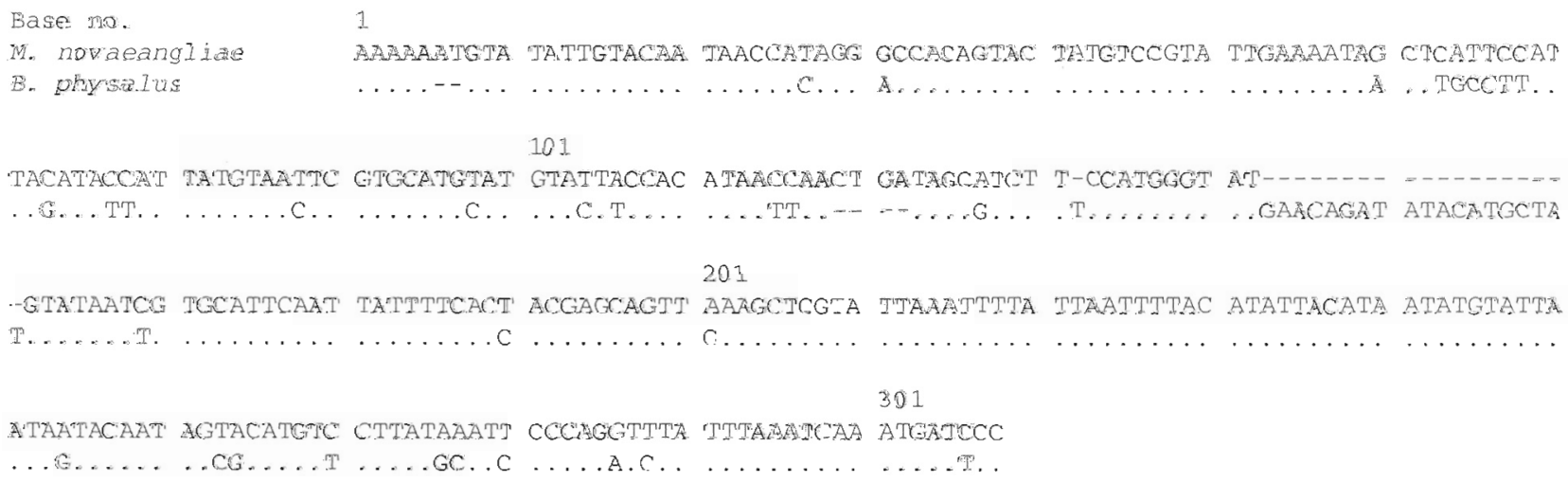

Fig. 1. Megaptera novaeangliae. The sequence of the first 288 nucleotides of the mt control region in haplotype no. 9 in Table 3 aligned with the published homologous sequence in the fin whale Balaenoptera physalus (Arnason et al. 1991). Dots indicate an identical nucleotide; hyphens were included to optimise alignment 
Table 3. Megaptera novaeanglian. Haplotype and gender for the analyzed specimens. The first column represents the haplotype number corresponding to the numbers in Figs. $2 \& 3$. The 4 middle columns show the polymorphic sites in the 31 haplotypes identified in the 136 analyzed specimens. The numbers above list the nucleotide position of the polymorphic site starting from the 5 ' end of the mitochondrial control region. Haplotypes 2 through 31 are listed with reference to haplotype number $1 . \cdots:$ a deletion $_{i}$ : an identical nucleotide at the position relative to haplotype number 1 ; A: adenine; C: cytosine; G: guanine; $T$ : thymine. The final columns list the ID numbers of the analyzed samples with respect to haplotype. The first 2 letters denote the sampling location, the first 2 digits the sampling year and the last 4 digits are a serial identification number. AP: Antarctic Peninsula; GL: Gulf of St. Lawrence; GM: Gulf of Maine; IL: Iceland; SB: Samana Bay; WG: West Greenland. ID numbers which are underlined are males; those not underlined are females. The following ID numbers of samples collected in Samana Bay were later matched to individuals previously observed in the Gulf of Maine: SB90004, SB90028, SB90036, SB90039, SB90063, SB90080, SB91019 or Newfoundland: SB90009, SB90013, SB90015, SB90019, SB90058, SB90073, SB90078 SB91003, SB91005, SB91008, SB91022, SB91039, SB91043

\begin{tabular}{|c|c|c|c|c|c|c|c|c|c|}
\hline & $\begin{array}{r}11 \\
112268801 \\
6387978940\end{array}$ & $\begin{array}{l}1111111111 \\
2233345666 \\
8978994458\end{array}$ & $\begin{array}{l}1122222222 \\
7844565666 \\
0629546789\end{array}$ & $\begin{array}{l}222222 \\
777788 \\
026767\end{array}$ & Sample I & ID nos & & & \\
\hline 1 & - TCCGCTTTC & TCAGTCATTA & TTGTCAGTTT & ATATTC & GL91100 & WG89016 & WG91011 & & \\
\hline \multirow[t]{3}{*}{ ? } & $\ldots \ldots \ldots$ & $\ldots \ldots \ldots$ & $\ldots T \ldots$ & $\ldots \ldots$ & GL90011 & GL90028 & GL91011 & GL91029 & GL91101 \\
\hline & & & & & SB90004 & SB91019 & GM90054 & IL91004 & $\underline{\mathrm{SB} 90009}$ \\
\hline & & & & & SB91039 & SB91043 & WG89001 & WG89008 & WG91002 \\
\hline & $\ldots \ldots \ldots$ & $\ldots \ldots G \ldots$ & $\ldots$. . . . & $\ldots \ldots$ & GL91022 & & & & \\
\hline 4 & $\ldots \ldots \ldots$ & $\ldots \ldots \ldots$ & $\ldots$ Т.... & $\ldots C$ & $\frac{\text { GM90015 }}{\text { WG88018 }}$ & GM90019 & GM90033 & GM90051 & WG88004 \\
\hline !: & $\ldots \ldots \ldots$ & $\ldots . \mathrm{T} \ldots$ & $\ldots$. . . . & $\ldots C$ & $\overline{\text { GL90019 }}$ & & & & \\
\hline 6 & $\ldots \ldots c$ & $\ldots \ldots \ldots$ & $\ldots \mathrm{T} \ldots$ & $\ldots \mathrm{CT}$ & GL91013 & SB91003 & & & \\
\hline 7 & $\ldots \ldots c$ & $\ldots \ldots \ldots$ & $\ldots$. & $\ldots c$ & SB90039 & SB91005 & & & \\
\hline \multirow[t]{2}{*}{8} & $\ldots \ldots c$ & $\ldots \ldots \ldots$ & $\ldots$. . . . & $\ldots c$. & GL91103 & IL91005 & IL91012 & IL91013 & WG89003 \\
\hline & & & & & WG89006 & WG89009 & WG89019 & & \\
\hline 9 & $\mathrm{~A} \ldots \mathrm{T} \ldots \mathrm{C}$ & $\ldots G$. & $\ldots T \ldots$ & $\ldots c$ & $\underline{I L 91003}$ & & & & \\
\hline 10 & $\ldots \ldots \ldots$ & $c \ldots \ldots$ & $\ldots$. . . . & $\ldots$. . & $\overline{\mathrm{AP} 89003}$ & AP89006 & GL91105 & & \\
\hline 11 & $\ldots \ldots \mathrm{C} . \mathrm{C}$ & $c \ldots \ldots$ & с . Т.... & $\ldots . c$ & GL91065 & & & & \\
\hline \multirow[t]{2}{*}{12} & $\ldots \ldots c . c$. & $c \ldots \ldots$ & $\ldots$. $\ldots$. & $\ldots$. & GL91064 & GM90008 & IL91010 & WG88025 & WG89005 \\
\hline & & & & & WG89013 & WG91003 & & & \\
\hline 13 & $\ldots \ldots \ldots$ & C....... & $\ldots T \ldots$ & .G.C. & GL91027 & & & & \\
\hline 14 & $\ldots \ldots c$ & c.... $\ldots$ & $\ldots$. . . . & . GAC. & WG88014 & & & & \\
\hline 15 & $\ldots \ldots \ldots \mathrm{CT}$ & $c \ldots \ldots$. . & $\ldots$. . . . & . G.C. & WG88001 & & & & \\
\hline 16 & $\ldots \ldots \ldots$ & $C \ldots \ldots C \cdot G$ & $\ldots$ T. . . & .G.C. & GM90056 & GM90057 & & & \\
\hline \multirow[t]{6}{*}{17} & $\ldots \ldots c$ & $c \ldots \ldots c \ldots$ & $\ldots \mathrm{T} \ldots$ & .G.C. & GL90007 & GL90015 & GL91028 & GL91104 & GM90013 \\
\hline & & & & & GM90021 & GM90024 & GM90028 & GM90034 & GM90035 \\
\hline & & & & & GM90041 & GM90055 & GM90059 & IL91001 & IL91002 \\
\hline & & & & & IL91006 & IL91008 & IL91009 & IL91016. & SB90058 \\
\hline & & & & & $\underline{\mathrm{SB} 90073}$ & $\underline{5891008}$ & WG88015 & WG88016 & WG89004 \\
\hline & & & & & WG89007 & WG89018 & WG91009 & WG91012 & \\
\hline 18 & $\ldots \mathrm{T} \ldots \mathrm{c}$ & $c \ldots \ldots c \ldots$ & $\ldots \mathrm{T} \ldots$ & .G.C. & IL 91015 & & & & \\
\hline 19 & ..AT.CA. & Ст..... & C..CT ...C & . G. $\mathrm{C}^{\prime} \mathrm{T}$ & AP89007 & AP89010 & & & \\
\hline 20 & $\lambda \ldots \mathrm{T} \cdot \mathrm{CA}$ & CT.A..... & C..CT ... & ..G.CT & $\overline{A P 89004}$ & AP89005 & & & \\
\hline 21 & $\ldots \ldots \mathrm{T} \cdot \mathrm{CA}$ & CT.A.... & C. CT... & ..G.CT & AP89009 & & & & \\
\hline 22 & $\ldots$. . . & CT.A..... & C.. CT... & . G.CT & AP89011 & AP89012 & & & \\
\hline \multirow[t]{4}{*}{23} & ...T. TC.C. & CT...T. C & $\mathrm{CC} \ldots \mathrm{T} \ldots \mathrm{C} \cdot \mathrm{C}$ & . CG.CT & GL90030 & $\overline{\text { SB990080 }}$ & GM90006 & GM90026 & SB90015 \\
\hline & & & & & $\underline{\text { SB } 90078}$ & SB91022 & WG88002 & WG88013 & WG88021 \\
\hline & & & & & WG88022 & WG88023 & WG89011 & WG89012 & WG91001 \\
\hline & & & & & WG91004 & WG91005 & WG91006 & WG91007. & WG91008 \\
\hline 24 & $\ldots$. TC.C. & $\mathrm{Cr} \ldots \ldots \mathrm{C}$ & CC..TG.C.C & $. \mathrm{CG} . \mathrm{CT}$ & GM90058 & & & & \\
\hline 25 & . T. .TC.C. & CT...T.C. & CC.TG.C.C & . CG. CT & SB90019 & & & & \\
\hline \multirow[t]{2}{*}{26} & ...TC.C. & $\mathrm{CT} \ldots \mathrm{T} . \mathrm{C}$ & $\mathrm{CC} . \mathrm{TG} \cdot \mathrm{C} \cdot \mathrm{C}$ & $. \mathrm{CG} . \mathrm{CT}$ & GL90004 & SB90063 & GM90011 & GM90012. & SB900 013 \\
\hline & & & & & WG88012 & WG88017 & WG89002 & WG89017 & \\
\hline 27 & . T. TC.C. & CT. . T . C & CC.T. .C.C & . CG.CT & GL91102 & & & & \\
\hline \multirow[t]{2}{*}{28} & $\ldots \ldots$. . C & $\mathrm{CT} \ldots \mathrm{T} \ldots \mathrm{C}$ & CC.T. . C.C & . CG.CT & GL90029 & GL90031 & GL91051 & SB90028 & $\underline{\text { SB900036 }}$ \\
\hline & & & & & WG88003 & WG88020 & WG89010 & & \\
\hline 29 & ...TC.C. & $\mathrm{CT} \ldots \mathrm{T} \ldots \mathrm{C}$ & C...T.C.C & $. \mathrm{CG} . \mathrm{CT}$ & GL91030 & GM90050 & & & \\
\hline 30 & $\mathrm{AC} \ldots \mathrm{T} \cdot \mathrm{CC}$ & $\mathrm{CT} \ldots \mathrm{T} \ldots \mathrm{C}$ & с..T... & .G.CT & AP89002 & & & & \\
\hline 31 & ...T.C. & C.G.T... & $\mathrm{C} \cdot \dot{A} \cdot \mathrm{T} \ldots \mathrm{CC}$ & $\mathrm{GC} . \mathrm{C}^{\prime} \mathrm{T}$ & AP89001 & & & & \\
\hline
\end{tabular}




\section{Homogeneity tests}

No heterogeneity was detected within the 6 areas between sexes, residents/non-residents, and years. Consequently, males and females in each area, as well as the residents/non-residents in the Gulf of Maine, were pooled in the subsequent homogeneity tests. Within the western North Atlantic (all North Atlantic feeding grounds except Iceland) no heterogeneity was found and consequently the samples from this area were pooled.

Significant degrees of heterogeneity were found between the Antarctic Peninsula and all North Atlantic areas, as well as between Iceland and all other North Atlantic regions (Table 4); the latter (Gulf of Maine, Gulf of St. Lawrence, Newfoundland and West Greenland) are hereinafter collectively referred to as the 'western North Atlantic'.

The 31 specimens from the Gulf of Maine included whales from 3 known maternal lineages. The analysis revealed that each lineage possessed a different haplotype. Although samples from all feeding grounds probably include related individuals we could only test any effects of such an inclusion for the Gulf of Maine. We removed all but 1 animal of each known maternal lineage in the Gulf of Maine sample and included the reduced sample in the pairwise comparisons with other feeding grounds. No additional heterogeneity was detected. There was a slight but non-significant increase in the nucleotide diversity in the reduced sample relative to the non-reduced Gulf of Maine sample.

\section{Nucleotide diversity}

The estimated nucleotide diversity for the total sample was $2.6 \%$. The estimates for the feeding aggregations within the western North Atlantic and the Antarctic Peninsula varied between 2.4 and $2.9 \%$ with no significant inter-area differences (Table 5). The nucleotide diversity in the Icelandic sample $(0.86 \%)$ was 3 times lower than in any of the western North Atlantic feeding aggregations.

Table $4 . K_{S T}$ values (indicating the extent of genetic differentiation) in pairwise comparisons and the significance level. $\cdots p<0.01 ; \cdots p<0.001$

\begin{tabular}{|lcc|}
\hline & $\begin{array}{c}\text { Antarctic } \\
\text { Peninsula }\end{array}$ & $\begin{array}{c}\text { Western } \\
\text { North } \\
\text { Atlantic }\end{array}$ \\
\hline Antarctic Peninsula & & \\
$\begin{array}{l}\text { Western North Atlantic } \\
\text { Iceland }\end{array}$ & $0.047 \cdots$ & \\
& $0.33 \cdots$ & $0.040 \cdots$ \\
\hline
\end{tabular}

Table 5. Megaptera novaeangliae. Estimates of the nucleotide diversity and standard error within each humpback whale feeding aggregation

\begin{tabular}{|lcc|}
\hline Feeding aggregation & Nucleotide diversity & SE \\
\hline Antarctic Peninsula & 0.024 & 0.0038 \\
Gulf of Maine & 0.025 & 0.0022 \\
Gulf of St. Lawrence & 0.025 & 0.0027 \\
Newfoundland & 0.029 & 0.0031 \\
West Greenland & 0.026 & 0.0010 \\
Iceland & 0.0086 & 0.0015 \\
\hline
\end{tabular}

\section{Estimated genealogy}

None of the estimated genealogies based on either the maximum likelihood or the Neighbor-joining method were statistically different. The tree with the highest log-likelihood value is shown in Fig. 2 and the majority rule consensus tree in Fig. 3 with the bootstrap values over $50 \%$. All estimated trees have the same basic topology, as indicated by the bootstrap values.

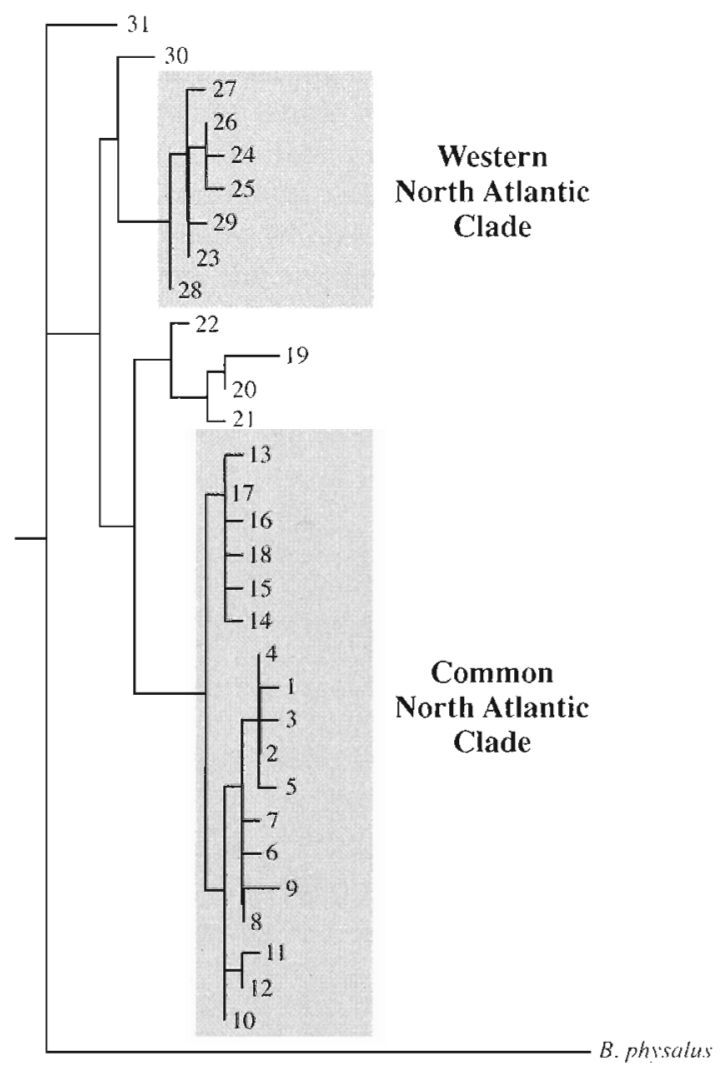

Fig. 2. Megaptera novaeangliae. Genealogy with the highest log-likelihood value. Numbers labeling the tip of the nodes correspond to the haplotype number in the far left column in Table 3. B. physalus: fin whale Balaenoptera physalus 


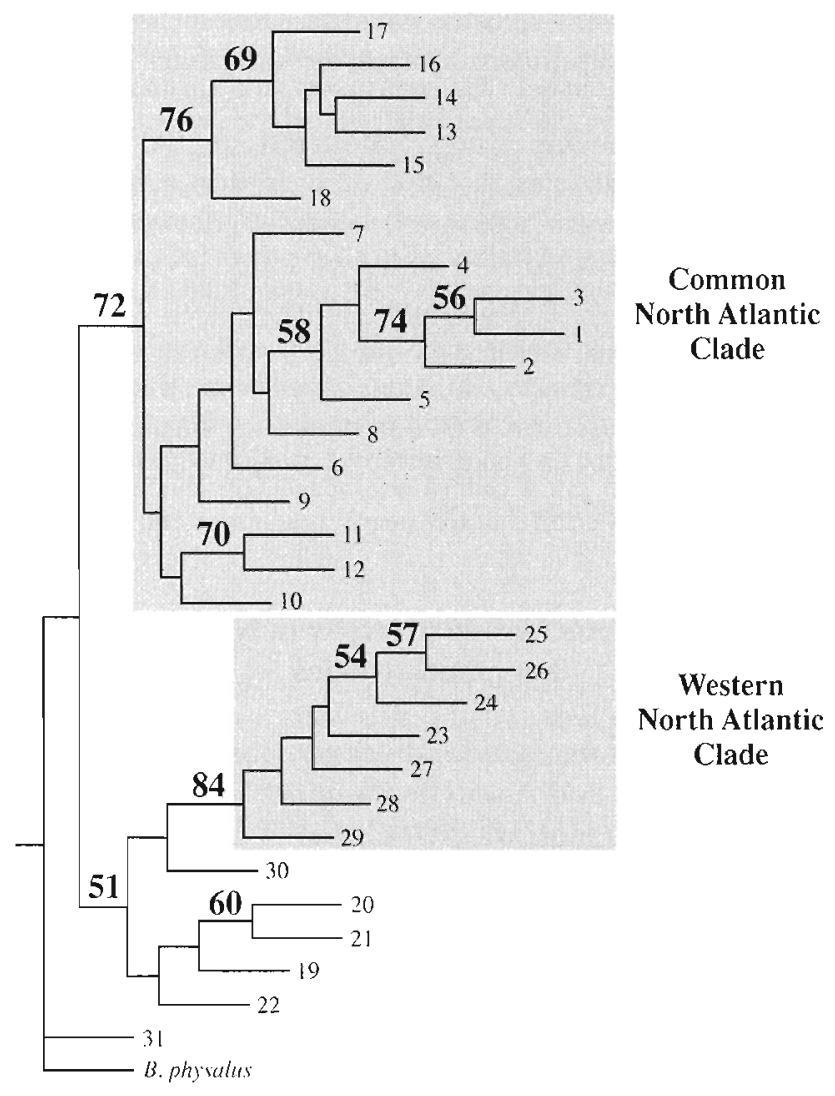

Fig. 3. Megaptera novaeangliae. The majority rule consensus genealogy estimated by the Neighbor-Joining method on 400 datasets created by bootstrapping. Large boldface numbers are bootstrap values. Numbers labeling the tip of the nodes correspond to the haplotype number in the far left column in Table 3. B. physalus: fin whale Balaenoptera physalus

The genealogy divides the 25 North Atlantic haplotypes into 2 major clades: we have termed these the 'Common North Atlantic' and the 'Western North Atlantic' (Fig. 2). The Western North Atlantic clade contains specimens from only the western part of the North Atlantic (Gulf of Maine, Gulf of Lawrence, Newfoundland and West Greenland).

The Common North Atlantic clade encompasses $72 \%$ (18 of 25 ) of the North Atlantic haplotypes accounting for $66 \%$ (83 of 125) of all North Atlantic specimens. The nucleotide diversity in the Common North Atlantic clade was estimated to be 0.010 $( \pm 0.00040 \mathrm{SE})_{i}$ this is 3 times higher than the nucleotide diversity within the Western North Atlantic clade $(0.0033 \pm 0.00043)$. Although direct comparison is impossible it seems that the Common North Atlantic clade is equivalent to clade ' $C D$ ', and the Western North Atlantic clade to clade ' $\mathrm{IJ}$ ' in the study by Baker et al. (1993).

\section{DISCUSSION}

\section{Maternally directed philopatry maintains long-term segregation between feeding aggregations}

Baker et al. (1993) compared 283 nucleotides of the $\mathrm{mt}$ control region in 90 specimens of which 34 were from the North Atlantic. They found no heterogeneity between the 3 feeding grounds Iceland $(n=3)$, Newfoundland $(n=12)$ and the Gulf of Maine $(n=16)$. The present study is based upon a larger sample representing more North Atlantic feeding aggregations. The finding that a group of matrilineally related humpbacks (in what appears to be a panmictic population; Mattila et al. 1989, Clapham et al. 1993b) migrates only to feeding grounds within the western North Atlantic illustrates that behaviour influences population structure on an evolutionary time scale. There are no known geographical or environmental barriers, nor any physiological mechanisms, which would prevent western North Atlantic clade individuals from migrating to the feeding grounds off Iceland. Humpback whales have been observed to undertake migrations of almost $8000 \mathrm{~km}$ (Stone et al. 1990). Despite this propensity for long-distance movements, the sole mechanism of maternally directed foraging area philopatry appears to maintain segregation between the western North Atlantic and Icelandic feeding aggregations.

\section{Lack of heterogeneity within the western North Atlantic}

The genetic homogeneity within the 112 specimens representing 4 western North Atlantic feeding aggregations is in contrast to the results of studies based upon the identification of individual humpback whales, which have convincingly demonstrated an annual and maternally directed fidelity to specific feeding areas within the western North Atlantic (Katona \& Beard 1990, Clapham et al. 1993a). Our results corresponds to those of Baker and coworkers (Baker et al. 1993), who found no heterogeneity within the western North Atlantic in their worldwide study which included 28 specimens from 2 feeding grounds, the Gulf of Maine and Newfoundland. This apparent genetic homogeneity could have several causes, the most immediate being a high degree of mixing within the western North Atlantic. However, this seems unlikely for 2 reasons. Although resightings of a number of individuals on more than one feeding ground demonstrate that movements between areas do indeed occur, such events represent a small fraction of all resightings, a tact which argues 
for limited mixing (Stevick et al. 1993). Whether sightings of individuals in more than one feeding ground could represent whales en route to a final migratory destination, or the existence of very large feeding ranges is presently unknown. Our attempt to divide the Gulf of Maine specimens into residents and non-residents resulted in no heterogeneity, which would have been expected if what we define as 'non-residents' were primarily whales in transit to another feeding ground, although the sample sizes clearly are very small.

A more probable cause for the lack of heterogeneity in the western North Atlantic is the difference in the time scale of events between the life histories of individual whales and the accumulation of nucleotide differences in the mt genome. The greater part of the feeding grounds used by humpback whales in the western North Atlantic became accessible only after the last glaciation some $10000 \mathrm{yr}$ ago (Johnsen et al. 1992). Even if the population had been structured into discrete matrilineally directed feeding aggregations since the retreat of the ice, a much greater time scale would probably be required for evolutionary processes (such as accumulation of a significant number of divergent base substitutions and stochastic lineage extinction) to create similar structuring at the genetic level.

\section{Gene flow between oceanic populations}

The estimated genealogy placed all North Atlantic samples in 1 of 2 well-supported but divergent clades. The Common North Atlantic clade includes haplotypes which represent specimens from all North Atantic feeding aggregations, while the western North Atlantic clade is comprised of haplotypes found solely among from the western North Atlantic humpbacks. The co-existence of whales descending from 2 such divergent clades in the North Atlantic (each of which is more closely related to Antarctic haplotypes than the other North Atlantic clade) indicates that the North Atlantic Ocean has been populated by significant influxes of humpback whales on 2 occasions.

In the worldwide study conducted by Baker and co-workers (Baker et al. 1993), 6 migration events between oceans were postulated to explain the estimated genealogy. In the current study we found 1 Gulf of St. Lawrence and 2 Antarctic specimens with an identical haplotype. Thus this study demonstrates such migration between oceans, in this case from the North Atlantic to the Southern Ocean, since the haplotype of the 3 specimens is estimated to be within the Common North Atlantic clade.

\section{High level of nucleotide diversity in North Atlantic humpback whales}

The overall nucleotide diversity observed in the North Atlantic and Antarctic humpback whales found in this study is high relative to that of other cetacean species in the North Atlantic (Table 6) and is similar to that observed in some human populations (Vigilant et al. 1991). The estimate is similar to that found in previous studies (Baker et al. 1993).

The high level of diversity (relative to other cetaceans) can be explained relatively easily by the above hypothesis of 2 independent influxes of humpbacks into the North Atlantic. Thus the North Atlantic population of humpback whales is currently composed of whales originating from 2 different populations. Within each of the 2 clades, the Common North Atlantic and the Western North Atlantic, the estimate of nucleotide diversity is at a level similar to that found in other North Atlantic populations of baleen whales, except the heavily exploited northern right whale Eubalaena glacialis. The Antarctic Peninsula feeding aggregation is believed to contain humpback whales from more than one breeding ground (Dawbin 1966) and is therefore expected to have a high diversity, as indeed appears to be the case.

Table 6. Estimates of nucleotide diversity in other North Atlantic cetaceans. RFLP: restriction fragment length polymorphisms

\begin{tabular}{|c|c|c|c|}
\hline Species & $\begin{array}{l}\text { No. of analyzed } \\
\text { specimens }\end{array}$ & $\begin{array}{c}\text { Gene and } \\
\text { method of analysis }\end{array}$ & $\begin{array}{c}\text { Nucleotide } \\
\text { diversity }\end{array}$ \\
\hline Minke whale Balaenoptera acutorostrata & 111 & First 303 nucleotides of $\mathrm{mt}$ control region & $0.0072^{4}$ \\
\hline Fin whale Balaenoptera physalus & 103 & First 288 nucleotides of $\mathrm{mt}$ control region & $0.012^{b}$ \\
\hline Northern right whale Eubalaena glacialis & 126 & RFL.P analysis of total $\mathrm{mt}$ genome & $0.0026^{r}$ \\
\hline Humpback whale Megaptera novaeangliae & 136 & First 288 nucleotides of mt control region & $0.026^{\mathrm{d}}$ \\
\hline Narwhal Monodon monoceros & 206 & First 287 nucleotides of mt control region & $0.0016^{\mathrm{e}}$ \\
\hline
\end{tabular}


Acknowledgements. We thank our colleagues at the Department of Population Biology, the Center for Coastal Studies, the Greenland Fisheries Research Institute, the Mingan Island Cetacean Study, Inc., Haffrannstofnuninn and CIBIMA for support and assistance in numerous ways. Terje Härkonen and Mads-Peter Heide-Jørgensen are thanked for the Antarctic samples, Allied Whale lor fast and efficient matching of important photos, as well as Drs Volker Loeschcke and Jotun Hein and 3 anonymous reviewers for comments on the manuscript. For technical assistance with the molecular analyses we thank Christina Fæerch-Jensen, Martine Bérubé and Hanne Jørgensen and, with the photos, Lisa Baraff. The work was supported by the involved institutions, as well as the University of Copenhagen, the Commission for Scientific Research in Greenland, the Greenland Home Rule, Age V. Jensens Charity Foundation and World Wildlife Fund Denmark.

\section{LITERATURE CITED}

Amos, W., Hoelzel, A. R. (1991). Long-term preservation of whale skin for DNA analysis. In: Hoelzel, A. R. (ed.) Genetic ecology of whales and dolphins. Rep. int. Whal Commn (spec. iss. 13): 99-104

Arnason, U., Gullberg, A., Widegren, B. (1991). The complete sequence of the mitochondrial DNA of the fin whale, Balaenoptera physalus. J. molec. Evol. 33: 556-568

Arnason, U., Gullberg, A., Widegren, B. (1993). Cetacean mitochondrial DNA control region: sequences of all extant baleen whales and two sperm whale species. Molec. Biol. Evol. 10: 960-970

Baker, C. S., Palumbi, S. R., Lambertsen, R. H., Weinrich, M. T., Caldmbokidis, J., O'Brien, S. J. (1990). Influence of seasonal migration on geographic distribution of mitochondrial DNA haplotypes in humpback whales. Nature 344: $238-240$

Baker, C. S., Perry, A., Bannister, J. L., Weinrich, M. T., Abernethy, R. B., Calambodikis, J., Lien, J., Lambertsen, R. H., Urban Ramirez, J., Vasquez, O., Clapham, P. J., Alling, A., O'Brien, S. J., Palumbi, S. R. (1993). Abundant mitochondrial DNA variation and world-wide population structure in humpback whales. Proc. natl Acad. Sci. USA 90: 8239-8243

Brown, W. M. (1985). The mitochondrial genome of animals. In: Maclntyre, R. J. (ed.) Molecular evolutionary genetics. Plenum Press, New York, p. 95-130

Brown, W. M., George, M. Jr, Wilson, A. C. (1979). Rapid evolution of animal mitochondrial DNA. Proc. natl Acad. Sci. USA 76: $1967 \cdots 1971$

Cann, R. L., Brown, W. M., Wilson, A. C. (1984). Polymorphic sites and the mechanism of evolution in the human mitochondrial DNA. Genetics 106: 479-499

('hristensen, I., Haug, T., Øien, N. (1992). Seasonal distribution, exploitation and present abundance of stocks of large baleen whales (Mysticeti) and sperm whales (Physeter macrocephalus) in Norwegian and adjacent waters. ICES J. mar. Sci. 49: 341-355

Clapham, P. J., Baraff, L. S., Carlson, C. A., Christian, M. A., Mattila, D. K., Mayo, C. A., Murphy, M. A., Pittman, S. (1993a). Seasonal occurrence and annual return of humpback whales in the southern Gulf of Maine. Can. J. Zool. 71: 440-443

Clapham, P. J., Mattila, D. K., Palsbøll, P. J. (1993b). Lighlatitude-area composition of humpback whale groups in Samana Bay: further evidence for panmixis in the North Atlantic population. Can. J. Zool. 71: 1065-1066

Clapham, P. J., Palsbøll, P. J., Mattila, D. K. (1993c), High-en- ergy behaviors in humpback whales as a sourcr of sloughed skin for molecular analysis. Mar. Mammal Sci. 9: 182-194 Clapham, P. J., Mayo, C. A. (1987). Reproduction and recruitment of individually identified humpback whales, Megaptera novaeangliae, observed in Massachusetts Bay, 1979-1985. Can. J. Zool. 65: 2853-2863

Dawbin, W. H. (1966). The seasonal migratory cycle of the humpback whale. In: Norris, K. S. (ed.) Whales, dolphins and porpoises. Univ, of California Press, Berknley, p. $145-170$

Felsenstein, J. (1993). PHYLIP 3.5c. Manual and program available from Joe Felsenstein. Dept of Genetics SK-50, University of Washington, Seattle

Gyllensten, U. B., Erlich, H. A. (1988). Generation of singlestranded DNA by the polymerase reaction and its application to direct sequencing of the HLA-DQA locus. Proc. natl Acad. Sci. USA 85: 7652-7656

Hoelzel, A. R., Hancock, J. M., Dover, (i. A. (1991). Evolution of the cetacean mitochondrial control region. Molec. Biol. Evol. 8: 475-493

Hudson, R. R. (1992). Reply to Roff and Bentzen. Molec. Biol. Evol. 9: 969

I Iudson, R. R., Boos, D. D., Kaplan, N. L. (1992). A statistical test for detecting geographic subdivision. Molec. Biol. Evol. 9: 138-151

Johnsen, S. J., Clausen, H. B., Dansgaard, W., Fuhrer, K., Gundestrup, N., Hammer, C. V., Iversen, P., Jouzel, J., Stauffer, B., Steffensen, J. P. (1992). Irregular glacial interstidials recorded in a nnw Greenland ice core. Nature 359: 311-313

Katona, S. K., Beard, J. A. (1990). Population size, migrations, and feeding aggregations of the humpback whale, Megaptera novaeangliae, in the western North Atlantic Ocean. In: Hammond, P. S., Mizpoch, S. A., Donovan, G. P. (eds.) Individual recognition of cetaceans: Use of photoidentification and other techniques to estimate population parameters. Rep. int. Whal. Commn (spec. iss. 12): 253-282

Katona, S. K., Whitehead, H. P. (1981). Identifying humpback whales using their natural markings. Polar Record 20 : 439-444

Kimura, M. (1980). A simple method for estimating evolutionary rate of base substitutions through comparative studies of nucleotide sequences. J. molec. Evol. 16: 111-120

Kishino, H., Hasegawa, M. (1989). Evaluation of the maximum likelihood estimate of the evolutionary tree topologies from sequence data, and the branching order in Homonoidae. J. molec. Evol. 129: 170-179

Lambertsen, R. H. (1987). A biopsy system for large whales and its use for cytogenetics. J. Mammal. 68: 443-445

Maniatis, T., Fritsch, E. F., Sambrock, J. (1982). Molecular cloning. A laboratory manual. Cold Spring Harbor Laboratory, Cold Spring I larbor

Martin, A. R., Katona, S. K., Mattila, D., Hemuree, D., Waters, T. D. (1984). Migration of humpback whales between the Caribbean and Iceland. J. Mammal. 65: 330-333

Mattila, D. K., Clapham, P. J., Katona, S. K., Stone, G. S. (1989). Population composition of humpback whales, Megaptera novaeangliae, on Silver Bank, 1984. Can. J. Zool, 67: 281-285

Nei, M. (1982). Evolution of human races at the gene level. In: Bonne-Tamir, B., Cohen, T., Goodman, R. M. (eds.) Human genetics, part A: the unfolding genome. Alan R. Liss, New York, p. 167-181

Nei, M., Li, W.-H. (1979). Mathematical model for studying genetic variation in terms of restriction endonucleases. Proc. natl Acad. Sci. USA 76: 5269-5273 
Palsbøll, P. J., Larsen, F., Sigurd Hansen, E. (1991). Sampling of skin biopsies from free-ranging large cetaceans in West Greenland: development of new biopsy tips and bolt designs. Rep. int. Whal. Commn (spec. iss.) 13: 71-79

Palsbell, P. J., Vader, A., Bakke, I., El-Gewely, M. R. (1992). Gender determination in cetaceans by the polymerase chain reaction. (an. J. Zool. 70: 2166-2170

Payne, P. M., Wiley, D. N., Young, S. B., Pittman, S., Clapham, P. J., Jossi, J. W. (1990). Recent fluctuations in the abundance of baleen whales in the southern Gulf of Maine in relation to changes in selected prey. Fish. Bull. U.S. 88: $687-696$

Perkins, J., Balcomb, K. C., Nichols, G., Deavilla, M. (1984). Abundance and distribution of humpback whales, Megaptera novaeangliae, in West Greenland waters. Can. J. Fish. Aquat. Sci. 41: 533-536

Perkins, J., Whitehead, H. (1977). Observations on three species of baleen whales off northern Newfoundland and adjacent waters. J. Fish. Res. Bd Can. 34: 1436-1440

Roff, D. E., Bentzen, P. (1992). Detecting geographic subdivision: a comment on a paper by Hudson et al. Molec. Biol. Evol. 9: 968

Saiki, R. K., Gelfand, D. H., Stoffel, S., Scharf, S. J., Higuchi, R., Horn, G. T., Mullis, K. B., Erlich, H. A. (1988). Primerdirected enzymatic amplification of DNA with a thermo-

This article was submitted to the editor stable DNA polymerase. Science 239: 487-491

Saitou, N., Nei, M. (1987). The neighbour-joining method: a new method for reconstructing phylogenetic trees. Molec. Biol. Evol. 4: 406-425

Sigurjonsson, J., Gunnlaugsson, T. (1990). Recent trends in abundance of blue, Balaenoptera musculus, and humpback whales, Megaptera novaeangliae, off west and southwest Iceland based on systematic sightings records with a note on the occurrence of other cetacean species. Rep. int. Whal. Commn 40:537-551

Stevick, P. T., Allen, J. M., Katona, S. K. (1993). Dispersal patterns of humpback whales, Megaptera novaeangliae, in the western North Atlantic. 10th Conference on the Biology of Marine Mammals, Galvaston, Texas, 11-15 November. Marine Mammal Program, Texas A\&M University, Galvaston, TX, p. 103

Stone, G. S., Florez-Gonzalez, L., Katona, S. (1990). Whale migration record. Nature 346: 705

Upholt, W. B., Dawid, I. B. (1977). Mapping of mitochondrial DNA of individual sheep and goats: rapid evolution in the D loop region. Cell 11: 571-583

Vigilant, L., Stoneking, M., Harpending, H., Hawkes, K., Wilson, A. C. (1991). African populations and the evolution of human mitochondrial DNA. Science 253: 1503-1507

Manuscript first received: June 9, 1994

Revised version accepted: August 19, 1994 